Review

\title{
Consequences of EMT-Driven Changes in the Immune Microenvironment of Breast Cancer and Therapeutic Response of Cancer Cells
}

\author{
Snahlata Singh ${ }^{1}$ and Rumela Chakrabarti ${ }^{1, *}$ \\ Department of Biomedical Sciences, School of Veterinary Medicine, University of Pennsylvania, \\ Philadelphia, PA 19104, USA; snsingh@vet.upenn.edu \\ * Correspondence: rumela@vet.upenn.edu; Tel.: +215-746-1873; Fax: +215-573-5186
}

Received: 9 April 2019; Accepted: 4 May 2019; Published: 9 May 2019

check for updates

\begin{abstract}
Epithelial-to-mesenchymal transition (EMT) is a process through which epithelial cells lose their epithelial characteristics and cell-cell contact, thus increasing their invasive potential. In addition to its well-known roles in embryonic development, wound healing, and regeneration, EMT plays an important role in tumor progression and metastatic invasion. In breast cancer, EMT both increases the migratory capacity and invasive potential of tumor cells, and initiates protumorigenic alterations in the tumor microenvironment (TME). In particular, recent evidence has linked increased expression of EMT markers such as TWIST1 and MMPs in breast tumors with increased immune infiltration in the TME. These immune cells then provide cues that promote immune evasion by tumor cells, which is associated with enhanced tumor progression and metastasis. In the current review, we will summarize the current knowledge of the role of EMT in the biology of different subtypes of breast cancer. We will further explore the correlation between genetic switches leading to EMT and EMT-induced alterations within the TME that drive tumor growth and metastasis, as well as their possible effect on therapeutic response in breast cancer.
\end{abstract}

Keywords: breast cancer; subtypes; EMT; TWIST; MMPs; immune cells; TME; therapy resistance

\section{Introduction}

Breast cancer is a highly complex disease that has been classified into several subtypes based on morphological, immunohistochemical, and phenotypic characteristics of the tumor. The most commonly used classification is based on the presence or absence of hormone receptors. Breast cancers expressing estrogen (ER), progesterone (PR), and herceptin (HER2) receptors are termed hormone receptive while those that lack all three receptors are classified as hormone refractory or triple-negative breast cancer (TNBC) [1,2]. Such heterogeneity complicates choice of treatment options and highlights the critical need to study breast cancer in a subtype-specific manner.

Like other cancers, breast cancer is initiated by transformation of normal cells to cancerous ones. Following this transformation, epithelial-to-mesenchymal transition (EMT) plays an important role in enabling epithelial cells to acquire mesenchymal features and gain invasive potential [3-5], thereby driving cancer progression. During EMT, epithelial cells lose polarity and adhesive junctions that maintain cell-cell contact and undergo transformation to mesenchymal cells. Conversely, during mesenchymal-to-epithelial transformation (MET), tumor cells reacquire their epithelial characteristics and obtain cell-cell contact. MET is an essential step for tumor cells during colonization at the metastatic site [6-8]. EMT drives many developmental processes and is frequently observed in cancers, including breast cancer. EMT in the early stages of carcinogenesis is brought about by a switch in expression patterns of crucial genes, thereby initiating a cascade of cellular, molecular, 
and morphological changes in cells [3-5]. In addition to the dramatic effect of EMT on tumor cells, it brings a massive change in the dynamic landscape of the tumor microenvironment (TME). At the early stages of transformation, cytokines/chemokines secreted from tumor cells attract various stromal and immune cells to the TME $[9,10]$. These immune cells in turn provide a niche that facilitates tumor progression, invasion, and metastasis. Studies in the last decade have shown that immune cells in the TME determine the clinical outcome of the disease as well as the response of the tumor to chemo and immune therapy [11-15].

In this review, we will summarize the changes in gene expression during EMT leading to recruitment of immune cells in the TME that in turn facilitate progression, invasion, and metastasis of breast cancer. As breast cancer is notoriously heterogeneous and therapeutic regimen is decided according to the breast cancer subtype, we will focus on the role of EMT in different subtypes of breast cancer. We will also compile findings from studies describing how EMT-mediated changes in the immune landscape of the TME determine the therapeutic response of tumors.

\section{Breast Cancer Subtypes and Their Association with EMT}

As per the most recent molecular classification, breast cancer can be divided into the following subtypes: luminal A and B, HER2 positive, basal-like, and claudin-low. Luminal A and B breast cancers are generally ER $\alpha$-positive. Luminal B tumors show higher expression of Ki67 and are therefore highly proliferative and associated with a worse prognosis [16,17]. HER2-positive tumors express the oncogene ERBB2 on their membrane $[18,19]$. Basal-like tumors show high expression of basal cell markers and basal cytokeratins [20,21]. Claudin-low tumors are high in stem-cell-associated processes and display high expression of genes involved in EMT [22,23]. Basal-like and claudin-low subtypes usually lack all of the characterized hormone receptors such as ER, PR, and HER2 and are categorized as triple-negative breast cancer (TNBC).

Breast cancer cells arise from mammary epithelial cells that undergo various transcriptional, morphological, and biochemical changes, including EMT, that contribute to tumorigenesis. Normal mammary epithelial cells undergo EMT, a process that occurs in three distinctive phases, each bearing a distinct cassette of EMT-activating transcription factors (TFs). In the first phase, cells lose their polarity and acquire mesenchymal markers such as vimentin and fibronectin. After morphological changes, a switch in gene expression from epithelial-expressed E-CADHERIN to mesenchymal-expressed N-CADHERIN occurs that is mediated by ZEB1 and SNAIL and is maintained by GOOSECOID and FOXC2. During the third phase of EMT, mesenchymal cells acquire phenotypic and functional cancer stem cell (CSC) properties (CD44 ${ }^{\text {high }} \mathrm{CD} 24^{\text {low }}$, invasive, and tumorsphere-forming abilities) [24]. Acquisition of mesenchymal properties by tumor cells is associated with an upregulation of EMT transcriptional inducers such as TWIST1/2, SNAI2/SLUG, and ZEB1 [25-28]. Physiological regulators such as Notch receptors and ligands, along with Wnt ligands, can induce EMT in mammary epithelial cells. Notch and Wnt factors are also important for different steps of breast cancer initiation and progression [29-33]. In addition, EMT in normal mammary epithelial cells can be induced by overexpression of the apoptosis regulator B-cell lymphoma/leukemia gene 2 (BCL2), highlighting a novel role of BCL2 in EMT [34]. Sarrio et al. showed that the nontumorigenic basal cell lines MCF10A, MCF10-2A, and MCF12A contain an epithelial subpopulation which is epithelial cell adhesion molecule (EPCAM)-positive and spontaneously generates EPCAM negative mesenchymal cells through EMT that exhibit CSC $\left(\mathrm{CD} 44^{\text {high }} \mathrm{CD} 24^{\text {low }}\right)$ properties, as they are capable of forming tumorspheres and have increased invasive potential [25]. Consequently, it was suggested that EMT can increase the heterogeneity of the stem cell population in normal breast tissue, with a subset of epithelial cells displaying normal stem-cell-like features and a mesenchymal subset exhibiting CSC features that may contribute to tumor initiation and early dissemination. 


\subsection{Luminal $A$ and B Breast Cancers and EMT}

Tumors of the luminal A subtype are observed in the majority of breast cancer patients and both luminal subtypes $A$ and $B$ express $E R \alpha$. Although estrogen signaling is necessary for breast tumor growth [35], the ER $\alpha$ signaling pathway can inhibit EMT [36,37], raising the intriguing possibility that ER $\alpha$ expression could be responsible for the better prognosis of luminal $\mathrm{A}$ and $\mathrm{B}$ patients as compared to TNBC patients. Mechanistically, Ye et al. showed that ER $\alpha$ prevents EMT through repression of SLUG, either by directly decreasing its transcription or by repressing the nuclear coreceptor which binds to the SLUG promoter, thereby increasing expression of E-CADHERIN [36]. In a similar study, Wang et al. reported that ER $\alpha$ inhibits EMT by inhibiting RELB-dependent BCL2 expression in luminal breast cancer cell lines [37]. Alternatively, another study showed that ER $\alpha$ suppresses BM1 and therefore promotes stemness and EMT in breast cancer cells [38]. It will be interesting to determine how ER $\alpha$ signaling promotes these distinct functions in breast cancer cells and how these events are regulated in future experiments.

Extrinsic factors, like the multipotent cytokine transforming growth factor $\beta$ (TGF- $\beta$ ) stimulates EMT in breast cancers [39] and mechanistically, TGF- $\beta$ stimulation is associated with upregulation of SNAIL, TWIST, ZEB1/2 in luminal A and B breast cancer cell lines [40-42]. TGF- $\beta$-induced EMT activates EGFR-, IGF1R-, and MAPK-dependent ER $\alpha$ signaling and promotes antiestrogen resistance [43]. Similar to the TGF- $\beta$ pathway, the MEK-ERK pathway represses ESE1, a member of the ETS transcription factor family, resulting in upregulation of ETS1-regulated ZEBs. Therefore, activation of MEK-ERK positively correlates with an EMT phenotype in the luminal subtype of breast cancer $[44,45]$. Finally, in the luminal cancer cell line MCF7, VEGFR expression positively correlates with expression of SNAIL and N-CADHERIN, key regulators of EMT [46]. These studies suggest that while ER $\alpha$ can prevent EMT, environmental stimuli such as TGF- $\beta$ and activators of the MEK-ERK pathway can promote EMT in luminal cancer, indicating that the final outcome depends on a balance between these pathways.

\subsection{HER2-Positive Breast Cancer and EMT}

Similar to luminal subtypes of breast cancer, HER2-positive breast cancers also undergo TGF- $\beta$-dependent EMT. Chihara et al. showed that the TGF- $\beta$-SMAD3 pathway is critical for EMT in HER2-positive cancers [47]. Analysis of signaling pathways influencing TGF- $\beta$ expression in HER2-positive tumors revealed that silencing of AXL, a receptor tyrosine kinase that correlates with poor survival in HER2-positive patients, in a patient-derived xenograft reduces TGF- $\beta$, thereby impairing invasion [48]. Notably, HER2 directly regulates the production of TGF- $\beta$ and activation of TGF- $\beta / S M A D 3$ signaling [49]. This HER2/EGFR signaling controls the switch from a cell proliferative function for TGF- $\beta$ to promotion of cell migration [50], therefore making it a central player in the functional consequences of EMT in HER2-positive tumors.

Along with TGF- $\beta /$ SMAD3 signaling, upregulation of transcription factors SLUG and TWIST1 plays an important role in EMT in this breast cancer subtype. In HER2-positive breast cancer cell lines, MDA-MB-453 and BT474, Carpenter et al. showed that activation of AKT signaling upregulates SLUG expression [51]. However, clinical studies in which patients were categorized based on surface marker expressions showed that HER2-positive patients do not exhibit strong nuclear expression of SLUG [52], highlighting the need for further careful investigation. TWIST1, a known regulator of EMT, is highly phosphorylated on Serine 68 residue in HER2-positive invasive ductal carcinomas, thereby stabilizing the protein and promoting breast cancer invasiveness [53]. In addition, overexpression of HER2 in MCF7 luminal cells increased the expression of breast tumor kinase (Btk)/protein tyrosine kinase 6 (PTK-6) receptors, thereby augmenting EMT and invasive potential [54].

These studies collectively establish the role of TGF- $\beta$-associated pathways along with TWIST and SLUG genes in mediating EMT in HER2-positive breast cancer. Further studies are needed to identify novel pathways and mechanisms behind EMT in HER2-positive breast cancer. 


\subsection{TNBC or Basal-Like, Claudin-Low Breast Cancer and EMT}

TNBCs are the most aggressive subtype of breast cancer, with limited therapeutic options due to their lack of hormone-responsive receptors. Based on their molecular characteristics, TNBC can be further divided into different subtypes such as PAM50, Vanderbilt, Baylor, and French [55]. In addition, TNBCs can be classified into four categories; basal-like, mesenchymal, immunomodulatory, and luminal androgen receptor (AR)-positive subtypes [56]. In the basal-like subtype of TNBC, cell cycle and DNA damage response pathways are highly activated, so these tumors are often treated with platinum drugs and ADP-ribose polymerase (PARP) inhibitors that target these pathways [57-59]. Genome analysis of mesenchymal TNBC tumors shows high expression of gene clusters involved in growth factor signaling, such as PI3K/AKT, along with an increase in EMT gene signatures. Accordingly, these tumors are susceptible to mTOR inhibitors and eribulin mesylate, which is an inhibitor of EMT [60]. Immunomodulatory TNBCs are enriched in gene pathways related to immune cell signaling associated with immune cell recruitment, as well as signal transduction such as NFkB and JAK/STAT pathways. Thus, in patients with immunomodulatory TNBC, immune checkpoint inhibitors have yielded promising results [61,62]. Luminal androgen receptor (AR)-positive subtype tumors have high levels of androgen-associated signaling and are therefore responsive to androgen receptor blockade [63].

EMT-related factors that have been widely described in TNBC are Notch and Hedgehog, TGF- $\beta$, and WNTs. High Notch expression in tumor samples from TNBC patients correlates with poor survival [64]. NUMB, an evolutionary conserved protein important for cell fate determination, antagonizes Notch signaling to prevent EMT in TNBC [65]. JAGGED1, a Notch ligand, can activate Notch signaling to induce EMT through upregulation of SLUG, which in turn represses the expression of E-CADHERIN [66]. Another recent study has shown that the Notch receptor NOTCH3 is important for TNBC breast cancer growth [67]. Moreover, reports show that NOTCH1 and NOTCH4 represent potential biomarkers in TNBC due to their high expression [68]. However, their connection to EMT in breast cancer is not very clear and further studies are needed to confirm the involvement of Notch signaling at the level of each receptor and ligands for EMT in TNBC. Like the Notch pathway, the Hedgehog pathway is crucial for embryonic development and stem cell renewal, and has also been associated with EMT in breast cancer. Hedgehog signaling activates three glioma-associated oncogenes, GLI1, 2, and 3. By employing a high-throughput screen, Colavito et al. have identified GLI1 as a critical determinant of EMT in breast cancer cell lines [69]. Activation of GLI1 is also associated with hypoxia-induced EMT and invasive potential of MDA-MB-231 TNBC cells [70]. Other Hedgehog signaling factors like SHH, PTCH1, and GLI2 are overexpressed in breast cancer, but their connection to EMT is not well established in breast cancer [71,72].

As in other types of breast cancer, TGF- $\beta$-mediated regulation of N-CADHERIN, BCL2, and CYCLIN D1 determines EMT and stemness in MDA-MB-231 TNBC cells [73]. In addition, musculoaponeurotic fibrosarcoma (MAF) oncogene family protein K (MAFK) induces EMT in a TGF- $\beta$-dependent manner in TNBC cell lines [74]. These studies suggest that TGF- $\beta$ could be a universal master regulator of EMT in tumor cells. The functional importance of EMT in tumor progression was further demonstrated by addition of selective inhibitors of inducible nitric oxide synthase (iNOS), an enzyme associated with poor prognosis in TNBC patients. These inhibitors limited migration and self-renewal properties of TNBC cells along with reducing the levels of EMT transcription factors such as SNAIL, SLUG, TWIST1, and ZEB1 [75]. Interestingly, targeting $\beta 3$ integrins using nanoparticles-based siRNA inhibited EMT and metastasis in TNBC tumors by attenuating TGF- $\beta$ signaling [76]. Thus, TGF- $\beta$ is connected to EMT either directly or indirectly promoting breast cancer progression.

Aberrant Wnt signaling is a characteristic of TNBC, with both canonical and noncanonical pathways implicated in TNBC tumorigenesis and metastasis $[77,78]$. Enrichment of Wnt/ $\beta$-catenin signaling is evident in TNBC and is associated with poor clinical outcome within this subtype [78]. Earlier studies from our group showed that $\triangle \mathrm{NP} 63$, a transcription factor, upregulates FZD7, a Wnt receptor, thereby increasing Wnt signaling and EMT in normal mammary stem cells and basal subtype of breast cancer [77]. Along with Wnt activators, GSK3 $\beta$, a canonical Wnt pathway inhibitor, plays 
an important role in EMT in TNBC cells. A recent study shows that GSK3 $\beta$ is a potential therapeutic target for TNBCs and suggests that GSK3 $\beta$ inhibitors could serve as selective inhibitors of EMT and CSC function in the treatment of a subset of aggressive TNBC with more mesenchymal cells [79]. Another recent study shows that WNT10B, a noncanonical ligand, is important for EMT and CSC-like phenotypes in TNBC in a preclinical mouse model [80]. Together, these studies highlight that EMT is an integral part of multiple subsets of breast cancer. It can be regulated by diverse cell signaling mechanisms, and therapeutic targeting of EMT pathway may be beneficial, even in breast cancer subtypes that are notoriously treatment-resistant. We have summarized various genes and pathways responsible for EMT in different breast cancer subtypes in Table 1.

Table 1. Table shows genes and pathways involved in mediating EMT in different subtypes of breast.

\begin{tabular}{|c|c|c|c|}
\hline Breast Cancer Subtypes & Genes Involved & Signaling Pathways Involved & References \\
\hline Luminal $\mathrm{A}$ and $\mathrm{B}$ & $\begin{array}{c}\text { SLUG, BCL2, BM1, } \\
\text { TGF- } \beta, \text { TWIST, ZEB1/2, } \\
\text { ETS1, VEGFR }\end{array}$ & $\begin{array}{c}\text { ER } \alpha \text { signaling, TGF- } \beta \text { signaling, } \\
\text { EGFR-, IGFR-, } \\
\text { and MAPK-dependent, MEK-ERK }\end{array}$ & [36-46] \\
\hline HER2-positive & TGF- $\beta$, TWIST1, PTK-6 & $\begin{array}{c}\text { TGF- } \beta \text { signaling, AKT signaling, } \\
\text { HER2/EGFR signaling }\end{array}$ & {$[47-50,52-54]$} \\
\hline $\begin{array}{l}\text { TNBC (Basal and } \\
\text { Claudin-Low) }\end{array}$ & $\begin{array}{l}\text { TGF- } \beta, \text { GLI1, SNAIL, } \\
\text { SLUG, TWIST1, ZEB1, } \\
\triangle N P 63, \text { GSK3 } \beta\end{array}$ & $\begin{array}{c}\text { PI3K/AKT, Notch signaling, } \\
\text { Hedgehog signaling, Wnt signaling }\end{array}$ & {$[59,63-79]$} \\
\hline
\end{tabular}

\section{EMT Shapes the TME}

Multiple studies demonstrate that EMT is associated with increased dissemination and metastasis of tumor cells to other organs $[26,81,82]$. In part, this is due to the ability of tumor cells undergoing EMT to modulate the TME. Dvorak H.F. in 1986 in his highly cited article, "Tumors: wounds that do not heal: Similarities between tumor stromal generation and wound healing", explains how phenomena that occur within tumor stroma are similar to processes underway at a wound site [83]. Later studies by Coussens et al. suggested that precancerous cells are identified as a "wound" by mast cells [84], and similar to wounds, high numbers of platelets are found at sites of tumorigenesis [83,84]. Coussens and Hanahan went on to describe tumor growth as a biphasic event [85]. In the first phase, the body treats the tumor site as a wound and tumor growth is promoted by stromal cells. In the second phase, the tumor takes control of proinflammatory cytokines and shapes the TME to further support cancer growth and metastasis. Similar observations are seen in breast cancer where the tumor growth is aided by the TME and at the same time the TME confers proinvasive features to the tumor cells [86].

Based on these observations, it is critical to understand the transcriptional events within the tumor that have a subsequent impact on TME function, thereby influencing tumor progression. RUNX3, a member of the RUNX family of transcription factors, is frequently connected to breast cancer [87]. The immune suppressive role of RUNX3 has been reported in breast tumors via regulation of Tregs. A recent report found that RUNX3 binds to the promoter of FOXP3 and increases Treg population in the tumor microenvironment, which is associated with the progression of breast tumors [88]. However, RUNX3 has also been indicated as a tumor suppressor in breast cancer, which needs further careful evaluation [87]. Similar to RUNX3, the transcription factor GATA3 inhibits breast cancer progression and metastasis by altering the TME $[89,90]$. Furthermore, overexpression of members of the ETS family of transcription factors can promote increased numbers of immune cells in the TME to drive tumor progression. For example, complete deletion of ETS2 from epithelial and stromal cells in breast tumors leads to early hyperplastic growth and tumor formation by affecting MMP-3 and MMP-9 in macrophages in TME [91,92]. We have reported that ELF5, another member of the ETS family, suppresses EMT and metastasis of TNBC cells [93]. In an unpublished work from our lab, we have seen that loss of ELF5 in a preclinical TNBC mouse model not only enhances tumor growth and metastasis, but also leads to increased numbers of immune cells in the TME. Previously, we had 
shown that another transcription factor, $\triangle \mathrm{NP63}$, promotes stem cell activity in basal tumors [77] and that its expression positively correlates with EMT in basal tumors [77]. Recently, we showed that overexpression of $\triangle \mathrm{NP63}$ induces tumor cell production of CXCL2 and CCL22, chemokines responsible for recruitment of MDSCs and enhancing growth and metastasis of basal tumors [94]. P53, a tumor suppressor, regulates miRNAs to inhibit EMT and stem cells by regulation [95]. In a separate study, p53 levels were associated with increased numbers of lymphocytes in basal breast cancer [96]. These studies suggest that transcription factors intrinsic to tumors are important in shaping the TME. For a comprehensive understanding of how cancer cell intrinsic mechanisms such as transcription factors and other genes shape tumor immune microenvironment, please refer to the recent extensive review [97].

Preparation of tumor in premetastatic niches also involves modulation of the extracellular matrix (ECM). Matrix metalloproteinases (MMPs) are a group of 23 enzymes, 17 of which are secreted and 6 are membrane-bound. MMPs are implicated in modification of the ECM, leading to tumor development, migration, and invasion. MMP-3 or MMP-7 overexpression in the mammary epithelium generates premalignant lesions and spontaneous tumor formation [98,99]. On the contrary, MMP-11 knockout mice treated with the carcinogen 7,12-dimethylbenzanthracene (DMBA) develop fewer tumors than control [100]. While epithelial cells can produce MMPs that promote protumorigenic changes in the ECM, a few reports suggest that epithelial cells undergoing EMT can also give rise to myofibroblasts and stromal-like cells that are an essential part of tumor stroma [101,102]. These myofibroblasts produce additional MMPs to assist tumor growth and invasion [103-105].

In addition to modulating ECM at the site of tumor generation, epithelial cells undergoing EMT secrete soluble factors and cytokines to create an inflammatory environment for recruitment of lymphocytes, leucocytes, and other immune cells. Two of the well-studied cytokines produced by tumor cells are Interleukin 6 (IL-6) and IL-8. IL-6 is overexpressed in multiple cancers including breast cancer $[106,107]$ and high expression levels correlate with poor clinical outcomes in cancer patients [108]. IL-6 promotes tumorigenesis in a cancer cell autonomous manner as well as by influencing the differentiation of immune cells $[109,110]$, including B cells, T cells, and myeloid cells, and by promoting immunoglobulin production by B cells. Circulating IL-6 levels correlate with worsening prognosis in metastatic breast cancer patients and also correlate with the extent of the disease [111]. In breast cancer, IL-6 on tumor cells has been shown to induce EMT by repressing E-CADHERIN via STAT3 activation [112]. In another study involving multiple breast cancer subsets, IL-6 has been shown to increase cancer stem cell properties of tumor cells via EMT [113]. IL-6 levels also correlate to increased number of MDSCs, tumor-associated neutrophils (TANs), regulatory T cells (Tregs) in many cancers including breast cancer, suggesting that the consequent immune-suppressive environment contributes to cancer evasion [114]. Dominguez et al. reported that neutralization of IL-8 in TNBCs not only reduces their mesenchymalization but also reduces the number of polymorphonuclear MDSCs (PMN-MDSCs). This suggests that IL- 8 both promotes EMT in tumors and recruits immune cells involved in creating an immunosuppressive TME for progression and metastasis of tumor cells [115]. Together, these studies suggest that soluble factors and chemokines secreted by epithelial cells undergoing EMT play a critical role in restructuring the ECM and immune landscape to support tumor proliferation, progression, and metastasis.

\section{Regulation of EMT by Immune Cells in TME}

As detailed above, soluble factors released by cells undergoing EMT create an inflammatory milieu that promotes recruitment of immune cells to the site of tumorigenesis. These immune cells infiltrate the TME and assist tumor growth. In this subsection, we will highlight how different immune cells like macrophages, MDSCs, NK, and Tregs promote EMT and tumor progression in breast cancer.

Macrophages are monocytes that can be differentiated into M1 (antitumorigenic) and M2 (protumorigenic) phenotypes [116]. Recruitment of monocytes to the TME through stimuli such as CCL2/monocyte chemoattractant protein 1 (MCP-1) or colony-stimulating factor 1 (CSF-1) is well 
studied [117-119]. Stimulation of such monocytes with IL-4/IL-13, IL-10, or TGF- $\beta$ leads to generation of M2 macrophages [120] or TAMs which facilitate tumor angiogenesis and immune suppression, invasion, and metastasis by limiting the ability of $\mathrm{CD} 8^{+}$cytotoxic $\mathrm{T}$ cells. Macrophages are thought to promote early dissemination of cancer, angiogenesis, and metastasis by enhancing CSC-like features in tumor cells through EMT [121,122]. Specifically, TAMs secrete proangiogenic factors such as VEGF, PDGF, TGF- $\beta$ and MMPs, IL-6, and IL-1 to induce neovascularization and promote EMT [123-125]. Through modulation of the TME and ECM, TAMs provide a prometastatic environment for tumor cells. In ER-positive luminal cancer cells like MCF7 and T47D, secretory factors like MMP-9 promote invasive and migratory potential in cancer cells once they are cultured with macrophages [126]. Depletion of TAMs by anti-CSF1 antibody, which is a macrophage regulator, in a luminal breast cancer model leads to a reduction in tumor growth [127]. In this model, increased TAMs result in a TME rich in TGF- $\beta$, an inducer of EMT, and is associated with increased invasion by tumor cells. TAM numbers also correlate with EMT and low E-cadherin expression levels and can therefore be used as an unfavorable prognostic factor for TNBC [128]. These data suggest that TAMs may promote EMT in multiple breast subsets to promote tumor progression and metastasis. As such, defining the precise mechanisms regulating the differentiation of TAMs from infiltrating macrophages in breast cancer may provide crucial insight for therapeutic intervention.

Myeloid-derived suppressor cells (MDSCs) contribute to invasion and metastasis of cancer in multiple ways, but their primary action is through suppression of the antitumor immune response [129]. Myeloid cells infiltrating into the TME during initial stages of tumorigenesis differentiate into MDSCs in the chronic proinflammatory environment of the TME. Indeed, activated T cells secrete IFN- $\gamma$, which plays a crucial role in differentiation of MDSCs from myeloid cells [130,131]. These activated MDSCs express CD40 and PD-L1, which suppress the antitumor response of T cells [132,133]. Additionally, MDSCs produce Prostaglandins E2 that amplify MDSC populations in the TME [134]. Indoleamine 2,3-dioxygenase (IDO) is often expressed on tumor cells and are responsible for recruitment of MDSCs in creating an immune-suppressive environment [135] via regulatory T cells (TRegs) which produce kynurenine in several cancers like melanoma [136]. This suggests that therapeutic targeting of IDO could be one of the central regulators of immune suppression. Similar correlation between IDO and MDSC has been observed in metastatic breast cancer patients [137]. Future studies delineating the molecular mechanism of IDO-mediated recruitment of MDSCs in breast cancer may provide innovative therapeutic strategies.

In addition to the immune suppressive property of MDSCs, recent studies show a novel nonimmunologic function of MDSCs in increasing CSCs in breast cancer, which in turn makes the tumor cells more invasive and metastatic [138-140]. Our study showed that PMN MDSCs are higher in the basal subset of TNBC and are recruited in a $\triangle$ NP63-dependent manner [94]. In return, these MDSC secrete prometastatic factors that increase EMT gene signatures and CSC gene signatures in the TNBC cells, making them more invasive and metastatic. In another recent example using the 4T1 TNBC mouse model, it was shown that CXCR2 ${ }^{+}$MDSCs induces cancer cell EMT by IL- 6 and these CXCR2 ${ }^{+}$ MDSCs promotes $\mathrm{T}$ cell exhaustion, suggesting that CXCR2 ${ }^{+}$MDSCs may be a potential therapeutic target of TNBC [141]. Interestingly, MDSCs differentiate to tumor-associated macrophages in tumors, which are often more immune suppressive and support cancer stem cell properties. Together, MDSC and TAMs promote EMT and metastasis of breast cancer [142]. Thus, understanding the molecular mechanism of this differentiation step is integral to development of novel drugs targeting these immune-suppressive cells in breast cancer.

NK cells are classically known to induce antitumor immune responses [143,144]. However, multiple recent reports suggest that they may also promote tumor progression and metastasis in cancers in part by regulating EMT [145-147]. IL-18, present in the TME, can upregulate PD-1 expression on NK cells, resulting in an immune suppressive phenotype [148]. NK cells residing in tumors have a reduced antibody-dependent, cell-mediated cytotoxicity (ADCC) potential, thus limiting their antitumor activity $[149,150]$. Interestingly, tumor cells expressing Cell Adhesion Molecule 1 (CADM1), 
a cell adhesion molecule directly induced by the EMT-promoting TGF- $\beta$ pathway [151], are susceptible to NK cell-mediated cytotoxicity [152]. In a cohort of breast cancer patients, CADM1 expression correlated with improved patient survival [153]. While these studies point towards a strong association between NK cell function and EMT in tumors, further investigation on their role in tumorigenesis is required.

$\mathrm{T}$ cells are a critical regulatory factor in tumor biology. CD8+ cytotoxic $\mathrm{T}$ cells secrete antitumor cytokines such as TNF $\alpha$ and IFN- $\gamma$ that restrict the growth and metastasis of tumors [154-156].

However, CD8+ T cells within the TME frequently exhibit an "exhausted" phenotype due to overexposure to tumor antigens and/or the presence of immune suppressive antigens on tumor cells. Exhausted $\mathrm{T}$ cells neither produce antitumor cytokines nor undergo proliferation, thus restricting their antitumor activities [157]. In addition, FoxP3+ Tregs help tumor cells grow and metastasize through production of protumorigenic cytokines and expression of immunomodulatory receptors that suppress immune response and facilitate tumor growth [158]. Moreover, Tregs promote $\beta$-catenin-mediated EMT during radiation-induced pulmonary fibrosis [159], however, the molecular mechanism is not clear. In this regard, in our unpublished study, we have observed high levels of Treg infiltration in a preclinical murine model of TNBC undergoing EMT. Our future studies will establish the molecular mechanisms behind the association of Tregs and EMT in TNBC. Together, these reports collectively highlight that immune cells in the TME recruited during early stages of EMT additionally assist tumor cells in their proliferation, invasion, and metastasis in breast cancer.

\section{EMT, TME, and Therapeutic Resistance of Tumor Cells}

Resistance to therapy is one of the biggest challenges in tumor biology and was initially identified in the early 1990s in breast cancer cells [160]. EMT was implicated in conferring resistance to both conventional therapies such as radiation and chemotherapy and targeted therapies like the estrogen antagonists, Tamoxifen and Fulvestrant or cell cycle inhibitors, each used in specific subtypes of breast cancer. However, in recent years, immunotherapy has gained momentum. Under this section, we will discuss the effects of an EMT-driven protumorigenic TME on different therapeutic options, primarily focusing on chemo and immunotherapy resistance.

\subsection{Chemotherapy}

The response to chemotherapeutic drugs in breast cancer varies from patient to patient. Various groups have studied the correlation between the degree of response and immune cells present in the TME. Denkert C et al. 2010 showed that tumor-associated lymphocytes are an independent predictor of anthracycline/taxane response in breast cancer patients [161]. It is worth noting that these tumor-infiltrating lymphocytes could also promote EMT in multiple ways [162], further supporting the premise that the response to anthracycline/taxane could be dependent on EMT in tumor cells. In support, a recent study by Salvagno et al. demonstrated that targeting macrophages that are directly linked to EMT in tumors enhances the chemotherapeutic response of spontaneous mammary tumors [163]. In addition, Ladoire et al. observed that prior to neoadjuvant chemotherapy, patients display increased numbers of CD3-, CD8-, and FOXP3-positive cells [164]. However, patients who responded to therapy had significantly fewer FOXP3-positive cells than did nonresponders, in whom FOXP3-positive cells remained high. The authors concluded that high $\mathrm{CD}^{+}$and low $\mathrm{FOXP}^{+}$staining predicts a better response to neoadjuvant therapy in breast cancer. In contrast, other studies suggest that $\mathrm{TNF} \alpha$ secreted by $\mathrm{CD}^{+}$cells through sphingosine kinase mediates tamoxifen resistance in MCF7 cells $[165,166]$. Therefore, correlation of CD8+ cells secreting TNF $\alpha$ and tamoxifen response needs further evaluation.

A potential role for MDSC-mediated increases in CSCs in chemoresistance has also been noted. Specifically, Montero et al. observed that the number of circulating MDSCs in breast cancer patients increase upon Doxorubicin-cyclophosphamide chemotherapy [167]. As MDSCs promote EMT in tumor cells, the consequent increase in CSC-like properties $[139,168]$ could be responsible for decreased 
efficacy of Doxorubicin-cyclophosphamide in breast cancer patients. Together, these studies suggest that drug resistance to chemotherapy is linked to altered immune cells and cancer cells which needs to be studied in depth for better development of drugs against resistance.

Similar to chemotherapy, several monoclonal antibodies targeting immune cells such as Tregs (CD25 antibody) have shown some success in preclinical models, however, their function as monotherapy in established patient tumors is limited [169]. Moreover, antiangiogenic therapy with antibodies against vascular endothelial growth factor (VEGF) has not proven effective in patients with many tumor types, including breast cancer. VEGF has been shown to involve T cell development and therefore has been suggested to be connected to tumor-induced immune suppression [170]. It is recently shown that such resistance could be due to VEGF-mediated activation of IL-6 involving tumor microenvironment [171]. Trastuzumab, an FDA-approved anti-HER2 antibody, shows a 35\% response rate in metastatic breast cancer patients, however, exact mechanisms of action are still unknown. It is believed that Trastuzumab alters signaling activation of immune effector mechanisms. It would be interesting to determine if such resistance is due to involvement of EMT, tumor microenvironment, and immune cells [172].

\subsection{Immunotherapy}

TNBC tumors, which lack known hormone receptors, are insensitive to hormone-based therapies and are often resistant to chemo and radiotherapy. However, these tumors are highly immunogenic and therefore immunotherapy for treatment of TNBC may be particularly useful. Checkpoint inhibitors such as PD-1 (Nivolumab, Pembrolizumab), PD-L1 (Atezolizumab, Avelumab), and CTLA4 (Ipilimumab) block the immunomodulatory pathways between tumor cells and immune cells that assist in immune evasion and are currently in clinical trials. PD-L1 expression varies from $20 \%$ to $50 \%$ in all types of breast cancer subtypes $[173,174]$ and is higher in TNBC patients as compared to non-TNBC $[174,175]$. Accordingly, variable responses to checkpoint-based therapy could be dependent on expression levels of PD-L1 ligand on tumor cells. PD-L1 expression in EMT-activated breast cancer cells depends on the EMT-TF (ZEB1). Specifically, Noman et al. showed that mutual regulatory loop exists between two processes orchestrated by ZEB1, which functions as a transcriptional repressor of miR-200 that is able to activate the EMT program and as an activator of PD-L1 expression in tumor cells, leading to $\mathrm{CD}^{+} \mathrm{T}$ cells immunosuppression [176]. A similar correlation between PD-L1 and ZEB1 expression was found in nonsmall cell lung carcinoma (NSCLC) [177]. In NSCLC, patients with circulating tumor cells (CTCs) positive for PD-L1 were resistant to Nivolumab while those with PD-L1-negative CTCs were responsive [178,179]. Notably, these PD-L1-positive CTCs showed EMT features, identifying EMT as a predictive biomarker for response towards checkpoint inhibitors in breast, NSCLC, and other tumor types. Additionally, these results provide a novel preclinical rationale to explore EMT inhibitors as adjuvants to boost immunotherapeutic responses in subgroups of patients in whom malignant progression is driven by EMT-promoting transcription factors.

Checkpoint inhibitors in combination with chemotherapy drugs increase the rate of complete clinical response in several cancers including breast cancer. Pembrolizumab added to a neoadjuvant regimen consisting of cisplatin and doxorubicin increased the response of patients (NCT01042379) and similar observations have been observed with anti-PDL1 and anti-CTLA4 drugs. A combinatorial approach of more than one checkpoint inhibitor with chemotherapy for treatment of breast cancer patients is currently underway in clinical trial (NCT01928394). Along with designing combinatorial strategies of checkpoint inhibitors and chemotherapeutic drugs, researchers are also trying to inhibit immune cells such as T cells and M1 macrophages along with treatment with checkpoint blockers as potential strategies to overcome resistance to checkpoint inhibitors observed in some patients $[180,181]$. Together, these studies reveal that immune cells in the TME have a significant impact on the response of patients to different drugs, and suggest that regulation of EMT in tumor cells may provide a way to influence the immune landscape to increase therapeutic response. 


\section{Conclusions}

In this review, we have summarized the factors that determine EMT in different breast cancer subtypes and highlighted studies revealing how epithelial cancer cells undergoing EMT modulate the TME to promote tumorigenesis and enhance recruitment of immune cells. Notably, immune cell recruitment further enhances the ability of tumor cells to undergo EMT, thereby assisting in their tumor progression, invasion, and metastasis. Finally, we highlighted how immune cells and stromal components in TME determine the chemotherapeutic and immunotherapeutic response of patients. Resistance to checkpoint inhibitor-based immunotherapy can be answered through investigation of TME components. Blockade of their migration or recruitment into the tumor site may result in better immunotherapeutic response. The recruitment of immune cells into the tumor site is dependent on EMT in tumor cells. Thus future studies identifying novel combination therapies targeting immune cells in TME and tumor cells undergoing EMT will improve prognosis for breast cancer patients.

In a nutshell, a pictorial representation of the circuit between neoplastic mammary epithelial cells to mesenchymal cells and recruitment of immune cells in TME and its overall impact on therapy is provided in Figure 1.

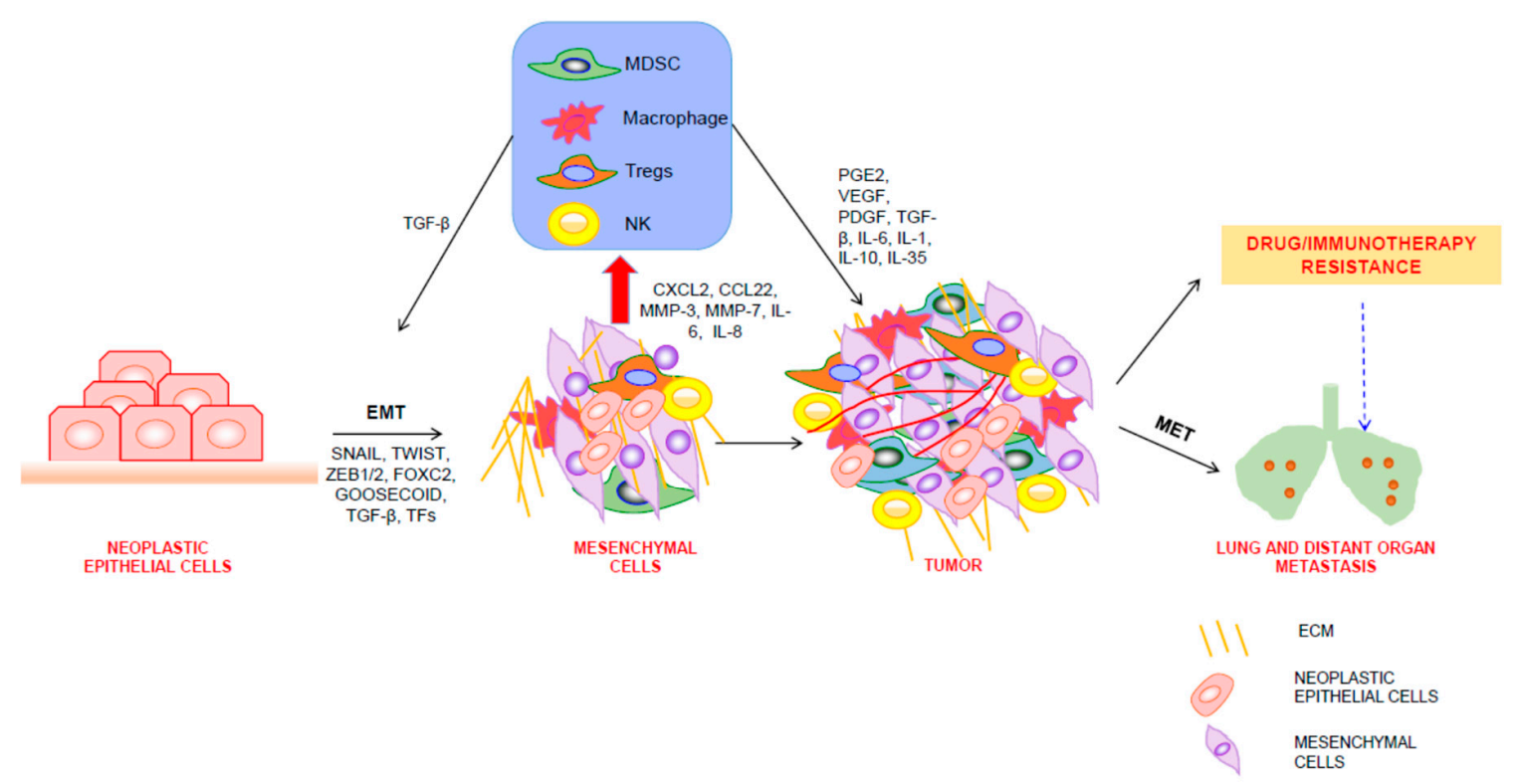

Figure 1. EMT, TME, and therapy. Neoplastic mammary epithelial cells undergoing transcriptional changes in key genes involved in EMT are transformed into mesenchymal cells. These mesenchymal cells secrete extracellular factors responsible for recruitment of immune cells and modulation of ECM. Recruited immune cells provide a proinflammatory milieu for growth of tumors by further secreting growth-promoting and prometastatic cytokines.

Author Contributions: Writing—review and editing, S.S. and R.C.; Visualization, S.S. and R.C.; supervision, S.S. and R.C.; project administration, S.S. and R.C.

Acknowledgments: We thank Leslie King, School of Veterinary Medicine, University of Pennsylvania for critical inputs on the review and helpful discussions.

Conflicts of Interest: The authors declare no conflict of interest.

\section{References}

1. Desmedt, C.; Haibe-Kains, B.; Wirapati, P.; Buyse, M.; Larsimont, D.; Bontempi, G.; Delorenzi, M.; Piccart, M.; Sotiriou, C. Biological processes associated with breast cancer clinical outcome depend on the molecular subtypes. Clin. Cancer Res. 2008, 14, 5158-5165. [CrossRef] 
2. Rouzier, R.; Perou, C.M.; Symmans, W.F.; Ibrahim, N.; Cristofanilli, M.; Anderson, K.; Hess, K.R.; Stec, J.; Ayers, M.; Wagner, P.; et al. Breast cancer molecular subtypes respond differently to preoperative chemotherapy. Clin. Cancer Res. 2005, 11, 5678-5685. [CrossRef] [PubMed]

3. Kalluri, R.; Weinberg, R.A. The basics of epithelial-mesenchymal transition. J. Clin. Investig. 2009, 119, 1420-1428. [CrossRef]

4. Lamouille, S.; Xu, J.; Derynck, R. Molecular mechanisms of epithelial-mesenchymal transition. Nat. Rev. Mol. Cell Biol. 2014, 15, 178-196. [CrossRef]

5. Thiery, J.P.; Sleeman, J.P. Complex networks orchestrate epithelial-mesenchymal transitions. Nat. Rev. Mol. Cell Biol. 2006, 7, 131-142. [CrossRef] [PubMed]

6. Del Pozo Martin, Y.; Park, D.; Ramachandran, A.; Ombrato, L.; Calvo, F.; Chakravarty, P.; Spencer-Dene, B.; Derzsi, S.; Hill, C.S.; Sahai, E.; et al. Mesenchymal Cancer Cell-Stroma Crosstalk Promotes Niche Activation. Epithelial Reversion, and Metastatic Colonization. Cell Rep. 2015, 13, 2456-2469. [CrossRef] [PubMed]

7. Stankic, M.; Pavlovic, S.; Chin, Y.; Brogi, E.; Padua, D.; Norton, L.; Massague, J.; Benezra, R. TGF-beta-Id1 signaling opposes Twist1 and promotes metastatic colonization via a mesenchymal-to-epithelial transition. Cell Rep. 2013, 5, 1228-1242. [CrossRef] [PubMed]

8. Gunasinghe, N.P.; Wells, A.; Thompson, E.W.; Hugo, H.J. Mesenchymal-epithelial transition (MET) as a mechanism for metastatic colonisation in breast cancer. Cancer Metastasis Rev. 2012, 31, 469-478. [CrossRef] [PubMed]

9. Brenot, A.; Knolhoff, B.L.; DeNardo, D.G.; Longmore, G.D. SNAIL1 action in tumor cells influences macrophage polarization and metastasis in breast cancer through altered GM-CSF secretion. Oncogenesis 2018, 7, 32. [CrossRef] [PubMed]

10. Cortes, M.; Sanchez-Moral, L.; de Barrios, O.; Fernandez-Acenero, M.J.; Martinez-Campanario, M.C.; Esteve-Codina, A.; Darling, D.S.; Gyorffy, B.; Lawrence, T.; Dean, D.C.; et al. Tumor-associated macrophages (TAMs) depend on ZEB1 for their cancer-promoting roles. EMBO J. 2017, 36, 3336-3355. [CrossRef]

11. De Palma, M.; Lewis, C.E. Macrophage regulation of tumor responses to anticancer therapies. Cancer Cell 2013, 23, 277-286. [CrossRef]

12. Hanahan, D.; Coussens, L.M. Accessories to the crime: Functions of cells recruited to the tumor microenvironment. Cancer Cell 2012, 21, 309-322. [CrossRef] [PubMed]

13. Swartz, M.A.; Iida, N.; Roberts, E.W.; Sangaletti, S.; Wong, M.H.; Yull, F.E.; Coussens, L.M.; DeClerck, Y.A. Tumor microenvironment complexity: Emerging roles in cancer therapy. Cancer Res. 2012, 72, 2473-2480. [CrossRef]

14. Taube, J.M.; Klein, A.; Brahmer, J.R.; Xu, H.; Pan, X.; Kim, J.H.; Chen, L.; Pardoll, D.M.; Topalian, S.L.; Anders, R.A. Association of PD-1. PD-1 ligands, and other features of the tumor immune microenvironment with response to anti-PD-1 therapy. Clin. Cancer Res. 2014, 20, 5064-5074. [CrossRef] [PubMed]

15. Quail, D.F.; Joyce, J.A. Microenvironmental regulation of tumor progression and metastasis. Nat. Med. 2013, 19, 1423-1437. [CrossRef]

16. Yerushalmi, R.; Woods, R.; Ravdin, P.M.; Hayes, M.M.; Gelmon, K.A. Ki67 in breast cancer: Prognostic and predictive potential. Lancet Oncol. 2010, 11, 174-183. [CrossRef]

17. Cheang, M.C.; Chia, S.K.; Voduc, D.; Gao, D.; Leung, S.; Snider, J.; Watson, M.; Davies, S.; Bernard, P.S.; Parker, J.S.; et al. Ki67 index. HER2 status, and prognosis of patients with luminal B breast cancer. J. Natl. Cancer Inst. 2009, 101, 736-750. [CrossRef] [PubMed]

18. Agus, D.B.; Akita, R.W.; Fox, W.D.; Lewis, G.D.; Higgins, B.; Pisacane, P.I.; Lofgren, J.A.; Tindell, C.; Evans, D.P.; Maiese, K.; et al. Targeting ligand-activated ErbB2 signaling inhibits breast and prostate tumor growth. Cancer Cell 2002, 2, 127-137. [CrossRef]

19. Yu, D.; Hung, M.C. Overexpression of ErbB2 in cancer and ErbB2-targeting strategies. Oncogene 2000, 19, 6115-6121. [CrossRef] [PubMed]

20. Rakha, E.A.; Reis-Filho, J.S.; Ellis, I.O. Basal-like breast cancer: A critical review. J. Clin. Oncol. 2008, 26, 2568-2581. [CrossRef] [PubMed]

21. Yehiely, F.; Moyano, J.V.; Evans, J.R.; Nielsen, T.O.; Cryns, V.L. Deconstructing the molecular portrait of basal-like breast cancer. Trends Mol. Med. 2006, 12, 537-544. [CrossRef]

22. De Craene, B.; Berx, G. Regulatory networks defining EMT during cancer initiation and progression. Nat. Rev. Cancer 2013, 13, 97-110. [CrossRef] [PubMed] 
23. Hennessy, B.T.; Gonzalez-Angulo, A.M.; Stemke-Hale, K.; Gilcrease, M.Z.; Krishnamurthy, S.; Lee, J.S.; Fridlyand, J.; Sahin, A.; Agarwal, R.; Joy, C.; et al. Characterization of a naturally occurring breast cancer subset enriched in epithelial-to-mesenchymal transition and stem cell characteristics. Cancer Res. 2009, 69, 4116-4124. [CrossRef]

24. Lindley, L.E.; Briegel, K.J. Molecular characterization of TGFbeta-induced epithelial-mesenchymal transition in normal finite lifespan human mammary epithelial cells. Biochem. Biophys. Res. Commun. 2010, 399, 659-664. [CrossRef] [PubMed]

25. Sarrio, D.; Franklin, C.K.; Mackay, A.; Reis-Filho, J.S.; Isacke, C.M. Epithelial and mesenchymal subpopulations within normal basal breast cell lines exhibit distinct stem cell/progenitor properties. Stem Cells 2012, 30, 292-303. [CrossRef]

26. Kang, Y.; Massague, J. Epithelial-mesenchymal transitions: Twist in development and metastasis. Cell 2004, 118, 277-279. [CrossRef] [PubMed]

27. Yang, J.; Mani, S.A.; Donaher, J.L.; Ramaswamy, S.; Itzykson, R.A.; Come, C.; Savagner, P.; Gitelman, I.; Richardson, A.; Weinberg, R.A. Twist, a master regulator of morphogenesis, plays an essential role in tumor metastasis. Cell 2004, 117, 927-939. [CrossRef] [PubMed]

28. Yang, J.; Weinberg, R.A. Epithelial-mesenchymal transition: At the crossroads of development and tumor metastasis. Dev. Cell. 2008, 14, 818-829. [CrossRef]

29. Braune, E.B.; Seshire, A.; Lendahl, U. Notch and Wnt Dysregulation and Its Relevance for Breast Cancer and Tumor Initiation. Biomedicines 2018, 6, 101. [CrossRef] [PubMed]

30. Cleary, A.S.; Leonard, T.L.; Gestl, S.A.; Gunther, E.J. Tumour cell heterogeneity maintained by cooperating subclones in Wnt-driven mammary cancers. Nature 2014, 508, 113-117. [CrossRef] [PubMed]

31. Cai, J.; Guan, H.; Fang, L.; Yang, Y.; Zhu, X.; Yuan, J.; Wu, J.; Li, M. MicroRNA-374a activates Wnt/beta-catenin signaling to promote breast cancer metastasis. J. Clin. Investig. 2013, 123, 566-579. [PubMed]

32. Kumar, S.; Srivastav, R.K.; Wilkes, D.W.; Ross, T.; Kim, S.; Kowalski, J.; Chatla, S.; Zhang, Q.; Nayak, A.; Guha, M.; et al. Estrogen-dependent DLL1-mediated Notch signaling promotes luminal breast cancer. Oncogene 2019, 38, 2092-2107. [CrossRef] [PubMed]

33. Yook, J.I.; Li, X.Y.; Ota, I.; Hu, C.; Kim, H.S.; Kim, N.H.; Cha, S.Y.; Ryu, J.K.; Choi, Y.J.; Kim, J.; et al. A Wnt-Axin2-GSK3beta cascade regulates Snail1 activity in breast cancer cells. Nat. Cell Biol. 2006, 8, 1398-1406. [CrossRef] [PubMed]

34. An, J.; Lv, J.; Li, A.; Qiao, J.; Fang, L.; Li, Z.; Li, B.; Zhao, W.; Chen, H.; Wang, L. Constitutive expression of Bcl-2 induces epithelial-Mesenchymal transition in mammary epithelial cells. BMC Cancer 2015, 15, 476. [CrossRef]

35. Reis-Filho, J.S.; Pusztai, L. Gene expression profiling in breast cancer: Classification. prognostication, and prediction. Lancet 2011, 378, 1812-1823. [CrossRef]

36. Ye, Y.; Xiao, Y.; Wang, W.; Yearsley, K.; Gao, J.X.; Shetuni, B.; Barsky, S.H. ERalpha signaling through slug regulates E-cadherin and EMT. Oncogene 2010, 29, 1451-1462. [CrossRef] [PubMed]

37. Wang, X.; Belguise, K.; Kersual, N.; Kirsch, K.H.; Mineva, N.D.; Galtier, F.; Chalbos, D.; Sonenshein, G.E. Oestrogen signalling inhibits invasive phenotype by repressing RelB and its target BCL2. Nat. Cell Biol. 2007, 9, 470-478. [CrossRef] [PubMed]

38. Wei, X.L.; Dou, X.W.; Bai, J.W.; Luo, X.R.; Qiu, S.Q.; Xi, D.D.; Huang, W.H.; Du, C.W.; Man, K.; Zhang, G.J. ERalpha inhibits epithelial-mesenchymal transition by suppressing Bmi1 in breast cancer. Oncotarget 2015, 6, 21704-21717. [CrossRef] [PubMed]

39. Massague, J. TGFbeta in Cancer. Cell 2008, 134, 215-230. [CrossRef]

40. Lehmann, W.; Mossmann, D.; Kleemann, J.; Mock, K.; Meisinger, C.; Brummer, T.; Herr, R.; Brabletz, S.; Stemmler, M.P.; Brabletz, T. ZEB1 turns into a transcriptional activator by interacting with YAP1 in aggressive cancer types. Nat. Commun. 2016, 7, 10498. [CrossRef]

41. Pang, M.F.; Georgoudaki, A.M.; Lambut, L.; Johansson, J.; Tabor, V.; Hagikura, K.; Jin, Y.; Jansson, M.; Alexander, J.S.; Nelson, C.M.; et al. TGF-beta1-induced EMT promotes targeted migration of breast cancer cells through the lymphatic system by the activation of CCR7/CCL21-mediated chemotaxis. Oncogene 2016, 35, 748-760. [CrossRef]

42. Peinado, H.; Quintanilla, M.; Cano, A. Transforming growth factor beta-1 induces snail transcription factor in epithelial cell lines: Mechanisms for epithelial mesenchymal transitions. J. Biol. Chem. 2003, 278, 21113-21123. [CrossRef] 
43. Tian, M.; Schiemann, W.P. TGF-beta Stimulation of EMT Programs Elicits Non-genomic ER-alpha Activity and Anti-estrogen Resistance in Breast Cancer Cells. J. Cancer Metastasis Treat. 2017, 3, 150-160. [CrossRef] [PubMed]

44. Xie, L.; Law, B.K.; Chytil, A.M.; Brown, K.A.; Aakre, M.E.; Moses, H.L. Activation of the Erk pathway is required for TGF-beta1-induced EMT in vitro. Neoplasia 2004, 6, 603-610. [CrossRef]

45. Janda, E.; Lehmann, K.; Killisch, I.; Jechlinger, M.; Herzig, M.; Downward, J.; Beug, H.; Grunert, S. Ras and TGF[beta] cooperatively regulate epithelial cell plasticity and metastasis: Dissection of Ras signaling pathways. J. Cell Biol. 2002, 156, 299-313. [CrossRef]

46. Ning, Q.; Liu, C.; Hou, L.; Meng, M.; Zhang, X.; Luo, M.; Shao, S.; Zuo, X.; Zhao, X. Vascular endothelial growth factor receptor-1 activation promotes migration and invasion of breast cancer cells through epithelial-mesenchymal transition. PLoS ONE 2013, 8, e65217. [CrossRef] [PubMed]

47. Chihara, Y.; Shimoda, M.; Hori, A.; Ohara, A.; Naoi, Y.; Ikeda, J.I.; Kagara, N.; Tanei, T.; Shimomura, A.; Shimazu, K.; et al. A small-molecule inhibitor of SMAD3 attenuates resistance to anti-HER2 drugs in HER2-positive breast cancer cells. Breast Cancer Res. Treat. 2017, 166, 55-68. [CrossRef]

48. Goyette, M.A.; Duhamel, S.; Aubert, L.; Pelletier, A.; Savage, P.; Thibault, M.P.; Johnson, R.M.; Carmeliet, P.; Basik, M.; Gaboury, L.; et al. The Receptor Tyrosine Kinase AXL Is Required at Multiple Steps of the Metastatic Cascade during HER2-Positive Breast Cancer Progression. Cell Rep. 2018, 23, 1476-1490. [CrossRef]

49. Gupta, P.; Srivastava, S.K. HER2 mediated de novo production of TGFbeta leads to SNAIL driven epithelial-to-mesenchymal transition and metastasis of breast cancer. Mol. Oncol. 2014, 8, 1532-1547. [CrossRef] [PubMed]

50. Huang, F.; Shi, Q.; Li, Y.; Xu, L.; Xu, C.; Chen, F.; Wang, H.; Liao, H.; Chang, Z.; Liu, F.; et al. HER2/EGFR-AKT Signaling Switches TGFbeta from Inhibiting Cell Proliferation to Promoting Cell Migration in Breast Cancer. Cancer Res. 2018, 78, 6073-6085. [CrossRef]

51. Carpenter, R.L.; Paw, I.; Dewhirst, M.W.; Lo,H.W. Akt phosphorylates and activates HSF-1 independent of heat shock, leading to Slug overexpression and epithelial-mesenchymal transition (EMT) of HER2-overexpressing breast cancer cells. Oncogene 2015, 34, 546-557. [CrossRef]

52. Pomp, V.; Leo, C.; Mauracher, A.; Korol, D.; Guo, W.; Varga, Z. Differential expression of epithelial-mesenchymal transition and stem cell markers in intrinsic subtypes of breast cancer. Breast Cancer Res. Treat. 2015, 154, 45-55. [CrossRef]

53. Hong, J.; Zhou, J.; Fu, J.; He, T.; Qin, J.; Wang, L.; Liao, L.; Xu, J. Phosphorylation of serine 68 of Twist1 by MAPKs stabilizes Twist1 protein and promotes breast cancer cell invasiveness. Cancer Res. 2011, 71, 3980-3990. [CrossRef]

54. Ai, M.; Liang, K.; Lu, Y.; Qiu, S.; Fan, Z. Brk/PTK6 cooperates with HER2 and Src in regulating breast cancer cell survival and epithelial-to-mesenchymal transition. Cancer Biol. Ther. 2013, 14, 237-245. [CrossRef]

55. Ahn, S.G.; Kim, S.J.; Kim, C.; Jeong, J. Molecular Classification of Triple-Negative Breast Cancer. J. Breast Cancer 2016, 19, 223-230. [CrossRef]

56. Lehmann, B.D.; Bauer, J.A.; Chen, X.; Sanders, M.E.; Chakravarthy, A.B.; Shyr, Y.; Pietenpol, J.A. Identification of human triple-negative breast cancer subtypes and preclinical models for selection of targeted therapies. J. Clin. Investig. 2011, 121, 2750-2767. [CrossRef] [PubMed]

57. Ibrahim, Y.H.; Garcia-Garcia, C.; Serra, V.; He, L.; Torres-Lockhart, K.; Prat, A.; Anton, P.; Cozar, P.; Guzman, M.; Grueso, J.; et al. PI3K inhibition impairs BRCA1/2 expression and sensitizes BRCA-proficient triple-negative breast cancer to PARP inhibition. Cancer Discov. 2012, 2, 1036-1047. [CrossRef]

58. Chuang, H.C.; Kapuriya, N.; Kulp, S.K.; Chen, C.S.; Shapiro, C.L. Differential anti-proliferative activities of poly(ADP-ribose) polymerase (PARP) inhibitors in triple-negative breast cancer cells. Breast Cancer Res Treat. 2012, 134, 649-659. [CrossRef]

59. Anders, C.K.; Winer, E.P.; Ford, J.M.; Dent, R.; Silver, D.P.; Sledge, G.W.; Carey, L.A. Poly(ADP-Ribose) polymerase inhibition: "targeted" therapy for triple-negative breast cancer. Clin. Cancer Res. 2010, 16, 4702-4710. [CrossRef]

60. Yoshida, T.; Ozawa, Y.; Kimura, T.; Sato, Y.; Kuznetsov, G.; Xu, S.; Uesugi, M.; Agoulnik, S.; Taylor, N.; Funahashi, Y.; et al. Eribulin mesilate suppresses experimental metastasis of breast cancer cells by reversing phenotype from epithelial-mesenchymal transition (EMT) to mesenchymal-epithelial transition (MET) states. Br. J. Cancer 2014, 110, 1497-1505. [CrossRef] [PubMed] 
61. Vikas, P.; Borcherding, N.; Zhang, W. The clinical promise of immunotherapy in triple-negative breast cancer. Cancer Manag. Res. 2018, 10, 6823-6833. [CrossRef] [PubMed]

62. Wang, X.; Qi, Y.; Kong, X.; Zhai, J.; Li, Y.; Song, Y.; Wang, J.; Feng, X.; Fang, Y. Immunological therapy: A novel thriving area for triple-negative breast cancer treatment. Cancer Lett. 2019, 442, 409-428. [CrossRef] [PubMed]

63. Gucalp, A.; Tolaney, S.; Isakoff, S.J.; Ingle, J.N.; Liu, M.C.; Carey, L.A.; Blackwell, K.; Rugo, H.; Nabell, L.; Forero, A.; et al. Phase II trial of bicalutamide in patients with androgen receptor-positive. estrogen receptor-negative metastatic Breast Cancer. Clin. Cancer Res. 2013, 19, 5505-5512. [CrossRef] [PubMed]

64. Mittal, S.; Sharma, A.; Balaji, S.A.; Gowda, M.C.; Dighe, R.R.; Kumar, R.V.; Rangarajan, A. Coordinate hyperactivation of Notch1 and Ras/MAPK pathways correlates with poor patient survival: Novel therapeutic strategy for aggressive breast cancers. Mol. Cancer Ther. 2014, 13, 3198-3209. [CrossRef] [PubMed]

65. Zhang, J.; Shao, X.; Sun, H.; Liu, K.; Ding, Z.; Chen, J.; Fang, L.; Su, W.; Hong, Y.; Li, H.; et al. NUMB negatively regulates the epithelial-mesenchymal transition of triple-negative breast cancer by antagonizing Notch signaling. Oncotarget 2016, 7, 61036-61053. [CrossRef]

66. Leong, K.G.; Niessen, K.; Kulic, I.; Raouf, A.; Eaves, C.; Pollet, I.; Karsan, A. Jagged1-mediated Notch activation induces epithelial-to-mesenchymal transition through Slug-induced repression of E-cadherin. J. Exp. Med. 2007, 204, 2935-2948. [CrossRef]

67. Choy, L.; Hagenbeek, T.J.; Solon, M.; French, D.; Finkle, D.; Shelton, A.; Venook, R.; Brauer, M.J.; Siebel, C.W. Constitutive NOTCH3 Signaling Promotes the Growth of Basal Breast Cancers. Cancer Res. 2017, 77, 1439-1452. [CrossRef] [PubMed]

68. Speiser, J.; Foreman, K.; Drinka, E.; Godellas, C.; Perez, C.; Salhadar, A.; Ersahin, C.; Rajan, P. Notch-1 and Notch-4 biomarker expression in triple-negative breast cancer. Int. J. Surg. Pathol. 2012, 20, 139-145. [CrossRef]

69. Colavito, S.A.; Zou, M.R.; Yan, Q.; Nguyen, D.X.; Stern, D.F. Significance of glioma-associated Oncogene homolog 1 (GLI1) expression in claudin-low breast cancer and crosstalk with the nuclear factor kappa-light-chain-enhancer of activated B cells (NFkappaB) pathway. Breast Cancer Res. 2014, 16, 444. [CrossRef]

70. Lei, J.; Fan, L.; Wei, G.; Chen, X.; Duan, W.; Xu, Q.; Sheng, W.; Wang, K.; Li, X. Gli-1 is crucial for hypoxia-induced epithelial-mesenchymal transition and invasion of breast cancer. Tumour Biol. 2015, 36, 3119-3126. [CrossRef] [PubMed]

71. Hui, M.; Cazet, A.; Nair, R.; Watkins, D.N.; O'Toole, S.A.; Swarbrick, A. The Hedgehog signalling pathway in breast development. carcinogenesis and cancer therapy. Breast Cancer Res. 2013, 15, 203. [CrossRef] [PubMed]

72. Woodward, W.A.; Chen, M.S.; Behbod, F.; Rosen, J.M. On mammary stem cells. J. Cell Sci. 2005, 118, 3585-3594. [CrossRef]

73. Xu, X.; Zhang, L.; He, X.; Zhang, P.; Sun, C.; Xu, X.; Lu, Y.; Li, F. TGF-beta plays a vital role in triple-negative breast cancer (TNBC) drug-resistance through regulating stemness, EMT and apoptosis. Biochem. Biophys. Res. Commun. 2018, 502, 160-165. [CrossRef] [PubMed]

74. Okita, Y.; Kimura, M.; Xie, R.; Chen, C.; Shen, L.T.; Kojima, Y.; Suzuki, H.; Muratani, M.; Saitoh, M.; Semba, K.; et al. The transcription factor MAFK induces EMT and malignant progression of triple-negative breast cancer cells through its target GPNMB. Sci. Signal. 2017, 10, eaak9397. [CrossRef] [PubMed]

75. Granados-Principal, S.; Liu, Y.; Guevara, M.L.; Blanco, E.; Choi, D.S.; Qian, W.; Patel, T.; Rodriguez, A.A.; Cusimano, J.; Weiss, H.L.; et al. Inhibition of iNOS as a novel effective targeted therapy against triple-negative breast cancer. Breast Cancer Res. 2015, 17, 25. [CrossRef] [PubMed]

76. Parvani, J.G.; Gujrati, M.D.; Mack, M.A.; Schiemann, W.P.; Lu, Z.R. Silencing beta3 Integrin by Targeted ECO/siRNA Nanoparticles Inhibits EMT and Metastasis of Triple-Negative Breast Cancer. Cancer Res. 2015, 75, 2316-2325. [CrossRef]

77. Chakrabarti, R.; Wei, Y.; Hwang, J.; Hang, X.; Andres Blanco, M.; Choudhury, A.; Tiede, B.; Romano, R.A.; DeCoste, C.; Mercatali, L.; et al. DeltaNp63 promotes stem cell activity in mammary gland development and basal-like breast cancer by enhancing Fzd7 expression and Wnt signalling. Nat. Cell Biol. 2014, 16, 1004-1015. [CrossRef] [PubMed] 
78. Khramtsov, A.I.; Khramtsova, G.F.; Tretiakova, M.; Huo, D.; Olopade, O.I.; Goss, K.H. Wnt/beta-catenin pathway activation is enriched in basal-like breast cancers and predicts poor outcome. Am. J. Pathol. 2010, 176, 2911-2920. [CrossRef] [PubMed]

79. Vijay, G.V.; Zhao, N.; Den Hollander, P.; Toneff, M.J.; Joseph, R.; Pietila, M.; Taube, J.H.; Sarkar, T.R.; Ramirez-Pena, E.; Werden, S.J.; et al. GSK3beta regulates epithelial-mesenchymal transition and cancer stem cell properties in triple-negative breast cancer. Breast Cancer Res. 2019, 21, 37. [CrossRef] [PubMed]

80. El Ayachi, I.; Fatima, I.; Wend, P.; Alva-Ornelas, J.A.; Runke, S.; Kuenzinger, W.L.; Silva, J.; Silva, W.; Gray, J.K.; Lehr, S.; et al. The WNT10B Network Is Associated with Survival and Metastases in Chemoresistant Triple-Negative Breast Cancer. Cancer Res. 2019, 79, 982-993. [CrossRef]

81. Thiery, J.P.; Lim, C.T. Tumor dissemination: An EMT affair. Cancer Cell 2013, 23, 272-273. [CrossRef]

82. Yu, M.; Bardia, A.; Wittner, B.S.; Stott, S.L.; Smas, M.E.; Ting, D.T.; Isakoff, S.J.; Ciciliano, J.C.; Wells, M.N.; Shah, A.M.; et al. Circulating breast tumor cells exhibit dynamic changes in epithelial and mesenchymal composition. Science 2013, 339, 580-584. [CrossRef]

83. Dvorak, H.F. Tumors: Wounds that do not heal. Similarities between tumor stroma generation and wound healing. N. Engl. J. Med. 1986, 315, 1650-1659.

84. Coussens, L.M.; Werb, Z. Inflammation and cancer. Nature 2002, 420, 860-867. [CrossRef]

85. Coussens, L.M.; Raymond, W.W.; Bergers, G.; Laig-Webster, M.; Behrendtsen, O.; Werb, Z.; Caughey, G.H.; Hanahan, D. Inflammatory mast cells up-regulate angiogenesis during squamous epithelial carcinogenesis. Genes Dev. 1999, 13, 1382-1397. [CrossRef]

86. Bissell, M.J.; Hines, W.C. Why don't we get more cancer? A proposed role of the microenvironment in restraining cancer progression. Nat. Med. 2011, 17, 320-329. [CrossRef]

87. Chuang, L.S.; Ito, Y. RUNX3 is multifunctional in carcinogenesis of multiple solid tumors. Oncogene 2010, 29, 2605-2615. [CrossRef] [PubMed]

88. Manandhar, S.; Lee, Y.M. Emerging role of RUNX3 in the regulation of tumor microenvironment. BMB Rep. 2018, 51, 174-181. [CrossRef]

89. Chou, J.; Lin, J.H.; Brenot, A.; Kim, J.W.; Provot, S.; Werb, Z. GATA3 suppresses metastasis and modulates the tumour microenvironment by regulating microRNA-29b expression. Nat. Cell Biol. 2013, 15, 201-213. [CrossRef]

90. Kouros-Mehr, H.; Bechis, S.K.; Slorach, E.M.; Littlepage, L.E.; Egeblad, M.; Ewald, A.J.; Pai, S.Y.; Ho, I.C.; Werb, Z. GATA-3 links tumor differentiation and dissemination in a luminal breast cancer model. Cancer Cell 2008, 13, 141-152. [CrossRef]

91. Tynan, J.A.; Wen, F.; Muller, W.J.; Oshima, R.G. Ets2-dependent microenvironmental support of mouse mammary tumors. Oncogene 2005, 24, 6870-6876. [CrossRef] [PubMed]

92. Man, A.K.; Young, L.J.; Tynan, J.A.; Lesperance, J.; Egeblad, M.; Werb, Z.; Hauser, C.A.; Muller, W.J.; Cardiff, R.D.; Oshima, R.G. Ets2-dependent stromal regulation of mouse mammary tumors. Mol. Cell Biol. 2003, 23, 8614-8625. [CrossRef]

93. Chakrabarti, R.; Hwang, J.; Andres Blanco, M.; Wei, Y.; Lukacisin, M.; Romano, R.A.; Smalley, K.; Liu, S.; Yang, Q.; Ibrahim, T.; et al. Elf5 inhibits the epithelial-mesenchymal transition in mammary gland development and breast cancer metastasis by transcriptionally repressing Snail2. Nat. Cell Biol. 2012, 14, 1212-1222. [CrossRef]

94. Kumar, S.; Wilkes, D.W.; Samuel, N.; Blanco, M.A.; Nayak, A.; Alicea-Torres, K.; Gluck, C.; Sinha, S.; Gabrilovich, D.; Chakrabarti, R. DeltaNp63-driven recruitment of myeloid-derived suppressor cells promotes metastasis in triple-negative breast cancer. J. Clin. Investig. 2018, 128, 5095-5109. [CrossRef] [PubMed]

95. Chang, C.J.; Chao, C.H.; Xia, W.; Yang, J.Y.; Xiong, Y.; Li, C.W.; Yu, W.H.; Rehman, S.K.; Hsu, J.L.; Lee, H.H.; et al. p53 regulates epithelial-mesenchymal transition and stem cell properties through modulating miRNAs. Nat. Cell Biol. 2011, 13, 317-323. [CrossRef] [PubMed]

96. Quigley, D.; Silwal-Pandit, L.; Dannenfelser, R.; Langerod, A.; Vollan, H.K.; Vaske, C.; Siegel, J.U.; Troyanskaya, O.; Chin, S.F.; Caldas, C.; et al. Lymphocyte Invasion in IC10/Basal-Like Breast Tumors Is Associated with Wild-Type TP53. Mol. Cancer Res. 2015, 13, 493-501. [CrossRef] [PubMed]

97. Wellenstein, M.D.; de Visser, K.E. Cancer-Cell-Intrinsic Mechanisms Shaping the Tumor Immune Landscape. Immunity 2018, 48, 399-416. [CrossRef] 
98. Ha, H.Y.; Moon, H.B.; Nam, M.S.; Lee, J.W.; Ryoo, Z.Y.; Lee, T.H.; Lee, K.K.; So, B.J.; Sato, H.; Seiki, M.; et al. Overexpression of membrane-type matrix metalloproteinase-1 gene induces mammary gland abnormalities and adenocarcinoma in transgenic mice. Cancer Res. 2001, 61, 984-990.

99. Sternlicht, M.D.; Lochter, A.; Sympson, C.J.; Huey, B.; Rougier, J.P.; Gray, J.W.; Pinkel, D.; Bissell, M.J.; Werb, Z. The stromal proteinase MMP3/stromelysin-1 promotes mammary carcinogenesis. Cell 1999, 98, 137-146. [CrossRef]

100. Masson, R.; Lefebvre, O.; Noel, A.; Fahime, M.E.; Chenard, M.P.; Wendling, C.; Kebers, F.; LeMeur, M.; Dierich, A.; Foidart, J.M.; et al. In vivo evidence that the stromelysin-3 metalloproteinase contributes in a paracrine manner to epithelial cell malignancy. J. Cell Biol. 1998, 140, 1535-1541. [CrossRef] [PubMed]

101. Li, J.H.; Wang, W.; Huang, X.R.; Oldfield, M.; Schmidt, A.M.; Cooper, M.E.; Lan, H.Y. Advanced glycation end products induce tubular epithelial-myofibroblast transition through the RAGE-ERK1/2 MAP kinase signaling pathway. Am. J. Pathol. 2004, 164, 1389-1397. [CrossRef]

102. Petersen, O.W.; Nielsen, H.L.; Gudjonsson, T.; Villadsen, R.; Rank, F.; Niebuhr, E.; Bissell, M.J.; Ronnov-Jessen, L. Epithelial to mesenchymal transition in human breast cancer can provide a nonmalignant stroma. Am. J. Pathol. 2003, 162, 391-402. [CrossRef]

103. Del Casar, J.M.; Gonzalez, L.O.; Alvarez, E.; Junquera, S.; Marin, L.; Gonzalez, L.; Bongera, M.; Vazquez, J.; Vizoso, F.J. Comparative analysis and clinical value of the expression of metalloproteases and their inhibitors by intratumor stromal fibroblasts and those at the invasive front of breast carcinomas. Breast Cancer Res. Treat. 2009, 116, 39-52. [CrossRef] [PubMed]

104. Vizoso, F.J.; Gonzalez, L.O.; Corte, M.D.; Rodriguez, J.C.; Vazquez, J.; Lamelas, M.L.; Junquera, S.; Merino, A.M.; Garcia-Muniz, J.L. Study of matrix metalloproteinases and their inhibitors in breast cancer. Br. J. Cancer 2007, 96, 903-911. [CrossRef]

105. Heppner, K.J.; Matrisian, L.M.; Jensen, R.A.; Rodgers, W.H. Expression of most matrix metalloproteinase family members in breast cancer represents a tumor-induced host response. Am. J. Pathol. 1996, 149, $273-282$.

106. Chang, Q.; Bournazou, E.; Sansone, P.; Berishaj, M.; Gao, S.P.; Daly, L.; Wels, J.; Theilen, T.; Granitto, S.; Zhang, X.; et al. The IL-6/JAK/Stat3 feed-forward loop drives tumorigenesis and metastasis. Neoplasia 2013, 15, 848-862. [CrossRef]

107. Lesina, M.; Kurkowski, M.U.; Ludes, K.; Rose-John, S.; Treiber, M.; Kloppel, G.; Yoshimura, A.; Reindl, W.; Sipos, B.; Akira, S.; et al. Stat3/Socs3 activation by IL-6 transsignaling promotes progression of pancreatic intraepithelial Neoplasia and development of pancreatic cancer. Cancer Cell 2011, 19, 456-469. [CrossRef]

108. Lippitz, B.E. Cytokine patterns in patients with cancer: A systematic review. Lancet Oncol. 2013, 14, e218-e228. [CrossRef]

109. Zhou, L.; Ivanov, I.I.; Spolski, R.; Min, R.; Shenderov, K.; Egawa, T.; Levy, D.E.; Leonard, W.J.; Littman, D.R. IL-6 programs $\mathrm{T}(\mathrm{H})-17$ cell differentiation by promoting sequential engagement of the IL-21 and IL-23 pathways. Nat. Immunol. 2007, 8, 967-974. [CrossRef]

110. Chomarat, P.; Banchereau, J.; Davoust, J.; Palucka, A.K. IL-6 switches the differentiation of monocytes from dendritic cells to macrophages. Nat. Immunol. 2000, 1, 510-514. [CrossRef] [PubMed]

111. Salgado, R.; Junius, S.; Benoy, I.; Van Dam, P.; Vermeulen, P.; Van Marck, E.; Huget, P.; Dirix, L.Y. Circulating interleukin-6 predicts survival in patients with metastatic breast cancer. Int. J. Cancer 2003, 103, 642-646. [CrossRef] [PubMed]

112. Sullivan, N.J.; Sasser, A.K.; Axel, A.E.; Vesuna, F.; Raman, V.; Ramirez, N.; Oberyszyn, T.M.; Hall, B.M. Interleukin-6 induces an epithelial-mesenchymal transition phenotype in human breast cancer cells. Oncogene 2009, 28, 2940-2947. [CrossRef]

113. Xie, G.; Yao, Q.; Liu, Y.; Du, S.; Liu, A.; Guo, Z.; Sun, A.; Ruan, J.; Chen, L.; Ye, C.; et al. IL-6-induced epithelial-mesenchymal transition promotes the generation of breast cancer stem-like cells analogous to mammosphere cultures. Int. J. Oncol. 2012, 40, 1171-1179.

114. Liu, Q.; Yu, S.; Li, A.; Xu, H.; Han, X.; Wu, K. Targeting interlukin-6 to relieve immunosuppression in tumor microenvironment. Tumour Biol. 2017, 39, 1010428317712445. [CrossRef]

115. Dominguez, C.; McCampbell, K.K.; David, J.M.; Palena, C. Neutralization of IL-8 decreases tumor PMN-MDSCs and reduces mesenchymalization of claudin-low triple-negative breast cancer. JCI Insight. 2017. [CrossRef]

116. Qian, B.Z.; Pollard, J.W. Macrophage diversity enhances tumor progression and metastasis. Cell 2010, 141, 39-51. [CrossRef] 
117. Yoshimura, T. The production of monocyte chemoattractant protein-1 (MCP-1)/CCL2 in tumor microenvironments. Cytokine 2017, 98, 71-78. [CrossRef]

118. Ding, J.; Guo, C.; Hu, P.; Chen, J.; Liu, Q.; Wu, X.; Cao, Y.; Wu, J. CSF1 is involved in breast cancer progression through inducing monocyte differentiation and homing. Int. J. Oncol. 2016, 49, 2064-2074. [CrossRef] [PubMed]

119. Condeelis, J.; Pollard, J.W. Macrophages: Obligate partners for tumor cell migration. invasion, and metastasis. Cell 2006, 124, 263-266. [CrossRef]

120. Georgoudaki, A.M.; Prokopec, K.E.; Boura, V.F.; Hellqvist, E.; Sohn, S.; Ostling, J.; Dahan, R.; Harris, R.A.; Rantalainen, M.; Klevebring, D.; et al. Reprogramming Tumor-Associated Macrophages by Antibody Targeting Inhibits Cancer Progression and Metastasis. Cell Rep. 2016, 15, 2000-2011. [CrossRef]

121. Linde, N.; Casanova-Acebes, M.; Sosa, M.S.; Mortha, A.; Rahman, A.; Farias, E.; Harper, K.; Tardio, E.; Reyes Torres, I.; Jones, J.; et al. Macrophages orchestrate breast cancer early dissemination and metastasis. Nat. Commun. 2018, 9, 21. [CrossRef] [PubMed]

122. Yang, M.; Ma, B.; Shao, H.; Clark, A.M.; Wells, A. Macrophage phenotypic subtypes diametrically regulate epithelial-mesenchymal plasticity in breast cancer cells. BMC Cancer 2016, 16, 419. [CrossRef]

123. Barbera-Guillem, E.; Nyhus, J.K.; Wolford, C.C.; Friece, C.R.; Sampsel, J.W. Vascular endothelial growth factor secretion by tumor-infiltrating macrophages essentially supports tumor angiogenesis. and IgG immune complexes potentiate the process. Cancer Res. 2002, 62, 7042-7049. [PubMed]

124. Muraoka, R.S.; Dumont, N.; Ritter, C.A.; Dugger, T.C.; Brantley, D.M.; Chen, J.; Easterly, E.; Roebuck, L.R.; Ryan, S.; Gotwals, P.J.; et al. Blockade of TGF-beta inhibits mammary tumor cell viability. migration, and metastases. J. Clin. Investig. 2002, 109, 1551-1559. [CrossRef] [PubMed]

125. Yu, Q.; Stamenkovic, I. Cell surface-localized matrix metalloproteinase-9 proteolytically activates TGF-beta and promotes tumor invasion and angiogenesis. Genes Dev. 2000, 14, 163-176. [PubMed]

126. Bednarczyk, R.B.; Tuli, N.Y.; Hanly, E.K.; Rahoma, G.B.; Maniyar, R.; Mittelman, A.; Geliebter, J.; Tiwari, R.K. Macrophage inflammatory factors promote epithelial-mesenchymal transition in breast cancer. Oncotarget 2018, 9, 24272-24282. [CrossRef]

127. Lin, E.Y.; Nguyen, A.V.; Russell, R.G.; Pollard, J.W. Colony-stimulating factor 1 promotes progression of mammary tumors to malignancy. J. Exp. Med. 2001, 193, 727-740. [CrossRef] [PubMed]

128. Zhang, W.J.; Wang, X.H.; Gao, S.T.; Chen, C.; Xu, X.Y.; Sun, Q.; Zhou, Z.H.; Wu, G.Z.; Yu, Q.; Xu, G.; et al. Tumor-associated macrophages correlate with phenomenon of epithelial-mesenchymal transition and contribute to poor prognosis in triple-negative breast cancer patients. J. Surg. Res. 2018, 222, 93-101. [CrossRef]

129. Veglia, F.; Perego, M.; Gabrilovich, D. Myeloid-derived suppressor cells coming of age. Nat. Immunol. 2018, 19, 108-119. [CrossRef]

130. Lindau, D.; Gielen, P.; Kroesen, M.; Wesseling, P.; Adema, G.J. The immunosuppressive tumour network: Myeloid-derived suppressor cells, regulatory T cells and natural killer T cells. Immunology 2013, 138, 105-115. [CrossRef]

131. Gabrilovich, D.I.; Nagaraj, S. Myeloid-derived suppressor cells as regulators of the immune system. Nat. Rev. Immunol. 2009, 9, 162-174. [CrossRef] [PubMed]

132. Noman, M.Z.; Desantis, G.; Janji, B.; Hasmim, M.; Karray, S.; Dessen, P.; Bronte, V.; Chouaib, S. PD-L1 is a novel direct target of HIF-1alpha. and its blockade under hypoxia enhanced MDSC-mediated T cell activation. J. Exp. Med. 2014, 211, 781-790. [CrossRef] [PubMed]

133. Huang, J.; Jochems, C.; Talaie, T.; Anderson, A.; Jales, A.; Tsang, K.Y.; Madan, R.A.; Gulley, J.L.; Schlom, J. Elevated serum soluble CD40 ligand in cancer patients may play an immunosuppressive role. Blood 2012, 120, 3030-3038. [CrossRef]

134. Sinha, P.; Clements, V.K.; Fulton, A.M.; Ostrand-Rosenberg, S. Prostaglandin E2 promotes tumor progression by inducing myeloid-derived suppressor cells. Cancer Res. 2007, 67, 4507-4513. [CrossRef]

135. Munn, D.H. Blocking IDO activity to enhance anti-tumor immunity. Front Biosci. 2012, 4, 734-745. [CrossRef]

136. Holmgaard, R.B.; Zamarin, D.; Li, Y.; Gasmi, B.; Munn, D.H.; Allison, J.P.; Merghoub, T.; Wolchok, J.D. Tumor-Expressed IDO Recruits and Activates MDSCs in a Treg-Dependent Manner. Cell Rep. 2015, 13, 412-424. [CrossRef] 
137. Yu, J.; Du, W.; Yan, F.; Wang, Y.; Li, H.; Cao, S.; Yu, W.; Shen, C.; Liu, J.; Ren, X. Myeloid-derived suppressor cells suppress antitumor immune responses through IDO expression and correlate with lymph node metastasis in patients with breast cancer. J. Immunol. 2013, 190, 3783-3797. [CrossRef]

138. Cui, T.X.; Kryczek, I.; Zhao, L.; Zhao, E.; Kuick, R.; Roh, M.H.; Vatan, L.; Szeliga, W.; Mao, Y.; Thomas, D.G.; et al. Myeloid-derived suppressor cells enhance stemness of cancer cells by inducing microRNA101 and suppressing the corepressor CtBP2. Immunity 2013, 39, 611-621. [CrossRef]

139. Peng, D.; Tanikawa, T.; Li, W.; Zhao, L.; Vatan, L.; Szeliga, W.; Wan, S.; Wei, S.; Wang, Y.; Liu, Y.; et al. Myeloid-Derived Suppressor Cells Endow Stem-like Qualities to Breast Cancer Cells through IL6/STAT3 and NO/NOTCH Cross-talk Signaling. Cancer Res. 2016, 76, 3156-3165. [CrossRef]

140. Welte, T.; Kim, I.S.; Tian, L.; Gao, X.; Wang, H.; Li, J.; Holdman, X.B.; Herschkowitz, J.I.; Pond, A.; Xie, G.; et al. Oncogenic mTOR signalling recruits myeloid-derived suppressor cells to promote tumour initiation. Nat. Cell Biol. 2016, 18, 632-644. [CrossRef] [PubMed]

141. Zhu, H.; Gu, Y.; Xue, Y.; Yuan, M.; Cao, X.; Liu, Q. CXCR2(+) MDSCs promote breast cancer progression by inducing EMT and activated T cell exhaustion. Oncotarget 2017, 8, 114554-114567. [CrossRef] [PubMed]

142. Ugel, S.; De Sanctis, F.; Mandruzzato, S.; Bronte, V. Tumor-induced myeloid deviation: When myeloid-derived suppressor cells meet tumor-associated macrophages. J. Clin. Investig. 2015, 125, 3365-3376. [CrossRef]

143. Fessenden, T.B.; Duong, E.; Spranger, S. A team effort: Natural killer cells on the first leg of the tumor immunity relay race. J. Immunother. Cancer 2018, 6, 67. [CrossRef] [PubMed]

144. Vivier, E.; Tomasello, E.; Baratin, M.; Walzer, T.; Ugolini, S. Functions of natural killer cells. Nat. Immunol. 2008, 9, 503-510. [CrossRef] [PubMed]

145. Huergo-Zapico, L.; Parodi, M.; Cantoni, C.; Lavarello, C.; Fernandez-Martinez, J.L.; Petretto, A.; DeAndres-Galiana, E.J.; Balsamo, M.; Lopez-Soto, A.; Pietra, G.; et al. NK-cell Editing Mediates Epithelial-to-Mesenchymal Transition via Phenotypic and Proteomic Changes in Melanoma Cell Lines. Cancer Res. 2018, 78, 3913-3925. [CrossRef]

146. Levi, I.; Amsalem, H.; Nissan, A.; Darash-Yahana, M.; Peretz, T.; Mandelboim, O.; Rachmilewitz, J. Characterization of tumor infiltrating natural killer cell subset. Oncotarget 2015, 6, 13835-13843. [CrossRef] [PubMed]

147. Bruno, A.; Ferlazzo, G.; Albini, A.; Noonan, D.M. A think tank of TINK/TANKs: Tumor-infiltrating/tumor-associated natural killer cells in tumor progression and angiogenesis. J. Natl. Cancer Inst. 2014, 106, dju200. [CrossRef]

148. Park, I.H.; Yang, H.N.; Lee, K.J.; Kim, T.S.; Lee, E.S.; Jung, S.Y.; Kwon, Y.; Kong, S.Y. Tumor-derived IL-18 induces PD-1 expression on immunosuppressive NK cells in triple-negative breast cancer. Oncotarget 2017, 8, 32722-32730. [CrossRef] [PubMed]

149. Berrien-Elliott, M.M.; Romee, R.; Fehniger, T.A. Improving natural killer cell cancer immunotherapy. Curr. Opin. Organ Transplant. 2015, 20, 671-680. [CrossRef] [PubMed]

150. Imai, K.; Matsuyama, S.; Miyake, S.; Suga, K.; Nakachi, K. Natural cytotoxic activity of peripheral-blood lymphocytes and cancer incidence: An 11-year follow-up study of a general population. Lancet 2000, 356, 1795-1799. [CrossRef]

151. Johansson, J.; Tabor, V.; Wikell, A.; Jalkanen, S.; Fuxe, J. TGF-beta1-Induced Epithelial-Mesenchymal Transition Promotes Monocyte/Macrophage Properties in Breast Cancer Cells. Front. Oncol. 2015, 5, 3. [CrossRef] [PubMed]

152. Faraji, F.; Pang, Y.; Walker, R.C.; Nieves Borges, R.; Yang, L.; Hunter, K.W. Cadm1 is a metastasis susceptibility gene that suppresses metastasis by modifying tumor interaction with the cell-mediated immunity. PLoS Genet. 2012, 8, e1002926. [CrossRef] [PubMed]

153. Chockley, P.J.; Chen, J.; Chen, G.; Beer, D.G.; Standiford, T.J.; Keshamouni, V.G. Epithelial-mesenchymal transition leads to NK cell-mediated metastasis-specific immunosurveillance in lung cancer. J. Clin. Investig. 2018, 128, 1384-1396. [CrossRef] [PubMed]

154. Halle, S.; Halle, O.; Forster, R. Mechanisms and Dynamics of T Cell-Mediated Cytotoxicity In Vivo. Trends Immunol. 2017, 38, 432-443. [CrossRef] [PubMed]

155. Martinez-Lostao, L.; Anel, A.; Pardo, J. How Do Cytotoxic Lymphocytes Kill Cancer Cells? Clin. Cancer Res. 2015, 21, 5047-5056. [CrossRef] [PubMed]

156. Pluhar, G.E.; Pennell, C.A.; Olin, M.R. CD8(+) T Cell-Independent Immune-Mediated Mechanisms of Anti-Tumor Activity. Crit. Rev. Immunol. 2015, 35, 153-172. [CrossRef] [PubMed] 
157. Chen, L.; Diao, L.; Yang, Y.; Yi, X.; Rodriguez, B.L.; Li, Y.; Villalobos, P.A.; Cascone, T.; Liu, X.; Tan, L.; et al. CD38-Mediated Immunosuppression as a Mechanism of Tumor Cell Escape from PD-1/PD-L1 Blockade. Cancer Discov. 2018, 8, 1156-1175. [CrossRef]

158. Takeuchi, Y.; Nishikawa, H. Roles of regulatory T cells in cancer immunity. Int. Immunol. 2016, 28, 401-409. [CrossRef]

159. Xiong, S.; Pan, X.; Xu, L.; Yang, Z.; Guo, R.; Gu, Y.; Li, R.; Wang, Q.; Xiao, F.; Du, L.; et al. Regulatory T Cells Promote beta-Catenin-Mediated Epithelium-to-Mesenchyme Transition During Radiation-Induced Pulmonary Fibrosis. Int. J. Radiat. Oncol. Biol. Phys. 2015, 93, 425-435. [CrossRef]

160. Sommers, C.L.; Heckford, S.E.; Skerker, J.M.; Worland, P.; Torri, J.A.; Thompson, E.W.; Byers, S.W.; Gelmann, E.P. Loss of epithelial markers and acquisition of vimentin expression in adriamycin- and vinblastine-resistant human breast cancer cell lines. Cancer Res. 1992, 52, 5190-5197.

161. Denkert, C.; Loibl, S.; Noske, A.; Roller, M.; Muller, B.M.; Komor, M.; Budczies, J.; Darb-Esfahani, S.; Kronenwett, R.; Hanusch, C.; et al. Tumor-associated lymphocytes as an independent predictor of response to neoadjuvant chemotherapy in breast cancer. J. Clin. Oncol. 2010, 28, 105-113. [CrossRef]

162. Chockley, P.J.; Keshamouni, V.G. Immunological Consequences of Epithelial-Mesenchymal Transition in Tumor Progression. J. Immunol. 2016, 197, 691-698. [CrossRef]

163. Salvagno, C.; Ciampricotti, M.; Tuit, S.; Hau, C.S.; van Weverwijk, A.; Coffelt, S.B.; Kersten, K.; Vrijland, K.; Kos, K.; Ulas, T.; et al. Therapeutic targeting of macrophages enhances chemotherapy efficacy by unleashing type I interferon response. Nat. Cell Biol. 2019, 21, 511-521. [CrossRef] [PubMed]

164. Ladoire, S.; Arnould, L.; Apetoh, L.; Coudert, B.; Martin, F.; Chauffert, B.; Fumoleau, P.; Ghiringhelli, F. Pathologic complete response to neoadjuvant chemotherapy of breast carcinoma is associated with the disappearance of tumor-infiltrating foxp3+ regulatory T cells. Clin. Cancer Res. 2008, 14, 2413-2420. [CrossRef]

165. Antoon, J.W.; White, M.D.; Burow, M.E.; Beckman, B.S. Dual inhibition of sphingosine kinase isoforms ablates TNF-induced drug resistance. Oncol. Rep. 2012, 27, 1779-1786. [PubMed]

166. Sukocheva, O.A. Expansion of Sphingosine Kinase and Sphingosine-1-Phosphate Receptor Function in Normal and Cancer Cells: From Membrane Restructuring to Mediation of Estrogen Signaling and Stem Cell Programming. Int. J. Mol. Sci. 2018, 19, 420. [CrossRef] [PubMed]

167. Diaz-Montero, C.M.; Salem, M.L.; Nishimura, M.I.; Garrett-Mayer, E.; Cole, D.J.; Montero, A.J. Increased circulating myeloid-derived suppressor cells correlate with clinical cancer stage. metastatic tumor burden, and doxorubicin-cyclophosphamide chemotherapy. Cancer Immunol. Immunother. 2009, 58, 49-59. [CrossRef] [PubMed]

168. Ouzounova, M.; Lee, E.; Piranlioglu, R.; El Andaloussi, A.; Kolhe, R.; Demirci, M.F.; Marasco, D.; Asm, I.; Chadli, A.; Hassan, K.A.; et al. Monocytic and granulocytic myeloid derived suppressor cells differentially regulate spatiotemporal tumour plasticity during metastatic cascade. Nat. Commun. 2017, 8, 14979. [CrossRef]

169. Arce Vargas, F.; Furness, A.J.S.; Solomon, I.; Joshi, K.; Mekkaoui, L.; Lesko, M.H.; Miranda Rota, E.; Dahan, R.; Georgiou, A.; Sledzinska, A.; et al. Fc-Optimized Anti-CD25 Depletes Tumor-Infiltrating Regulatory T Cells and Synergizes with PD-1 Blockade to Eradicate Established Tumors. Immunity 2017, 46, 577-586. [CrossRef]

170. Ohm, J.E.; Gabrilovich, D.I.; Sempowski, G.D.; Kisseleva, E.; Parman, K.S.; Nadaf, S.; Carbone, D.P. VEGF inhibits T-cell development and may contribute to tumor-induced immune suppression. Blood 2003, 101, 4878-4886. [CrossRef]

171. Incio, J.; Ligibel, J.A.; McManus, D.T.; Suboj, P.; Jung, K.; Kawaguchi, K.; Pinter, M.; Babykutty, S.; Chin, S.M.; Vardam, T.D.; et al. Obesity promotes resistance to anti-VEGF therapy in breast cancer by up-regulating IL-6 and potentially FGF-2. Sci. Transl. Med. 2018, 10. [CrossRef]

172. Luque-Cabal, M.; García-Teijido, P.; Fernández-Pérez, Y.; Sánchez-Lorenzo, L.; Palacio-Vázquez, I. Mechanisms Behind the Resistance to Trastuzumab in HER2-Amplified Breast Cancer and Strategies to Overcome It. Clin. Med. Insights Oncol. 2016, 10, 21-30. [CrossRef]

173. Barrett, M.T.; Lenkiewicz, E.; Malasi, S.; Basu, A.; Yearley, J.H.; Annamalai, L.; McCullough, A.E.; Kosiorek, H.E.; Narang, P.; Wilson Sayres, M.A.; et al. The association of genomic lesions and PD-1/PD-L1 expression in resected triple-negative breast cancers. Breast Cancer Res. 2018, 20, 71. [CrossRef] 
174. Mittendorf, E.A.; Philips, A.V.; Meric-Bernstam, F.; Qiao, N.; Wu, Y.; Harrington, S.; Su, X.; Wang, Y.; Gonzalez-Angulo, A.M.; Akcakanat, A.; et al. PD-L1 expression in triple-negative breast cancer. Cancer Immunol. Res. 2014, 2, 361-370. [CrossRef]

175. Muenst, S.; Soysal, S.D.; Gao, F.; Obermann, E.C.; Oertli, D.; Gillanders, W.E. The presence of programmed death 1 (PD-1)-positive tumor-infiltrating lymphocytes is associated with poor prognosis in human breast cancer. Breast Cancer Res. Treat. 2013, 139, 667-676. [CrossRef]

176. Noman, M.Z.; Janji, B.; Abdou, A.; Hasmim, M.; Terry, S.; Tan, T.Z.; Mami-Chouaib, F.; Thiery, J.P.; Chouaib, S. The immune checkpoint ligand PD-L1 is upregulated in EMT-activated human breast cancer cells by a mechanism involving ZEB-1 and miR-200. Oncoimmunology 2017, 6, e1263412. [CrossRef] [PubMed]

177. Chen, L.; Gibbons, D.L.; Goswami, S.; Cortez, M.A.; Ahn, Y.H.; Byers, L.A.; Zhang, X.; Yi, X.; Dwyer, D.; Lin, W.; et al. Metastasis is regulated via microRNA-200/ZEB1 axis control of tumour cell PD-L1 expression and intratumoral immunosuppression. Nat. Commun. 2014, 5, 5241. [CrossRef] [PubMed]

178. Nicolazzo, C.; Raimondi, C.; Mancini, M.; Caponnetto, S.; Gradilone, A.; Gandini, O.; Mastromartino, M.; Del Bene, G.; Prete, A.; Longo, F.; et al. Monitoring PD-L1 positive circulating tumor cells in non-small cell lung cancer patients treated with the PD-1 inhibitor Nivolumab. Sci. Rep. 2016, 6, 31726. [CrossRef] [PubMed]

179. Raimondi, C.; Carpino, G.; Nicolazzo, C.; Gradilone, A.; Gianni, W.; Gelibter, A.; Gaudio, E.; Cortesi, E.; Gazzaniga, P. PD-L1 and epithelial-mesenchymal transition in circulating tumor cells from non-small cell lung cancer patients: A molecular shield to evade immune system? Oncoimmunology 2017, 6, e1315488. [CrossRef] [PubMed]

180. Cassetta, L.; Kitamura, T. Targeting Tumor-Associated Macrophages as a Potential Strategy to Enhance the Response to Immune Checkpoint Inhibitors. Front. Cell Dev. Biol. 2018, 6, 38. [CrossRef]

181. Janakiram, M.; Abadi, Y.M.; Sparano, J.A.; Zang, X. T cell coinhibition and immunotherapy in human breast cancer. Discov. Med. 2012, 14, 229-236. [PubMed]

(C) 2019 by the authors. Licensee MDPI, Basel, Switzerland. This article is an open access article distributed under the terms and conditions of the Creative Commons Attribution (CC BY) license (http://creativecommons.org/licenses/by/4.0/). 